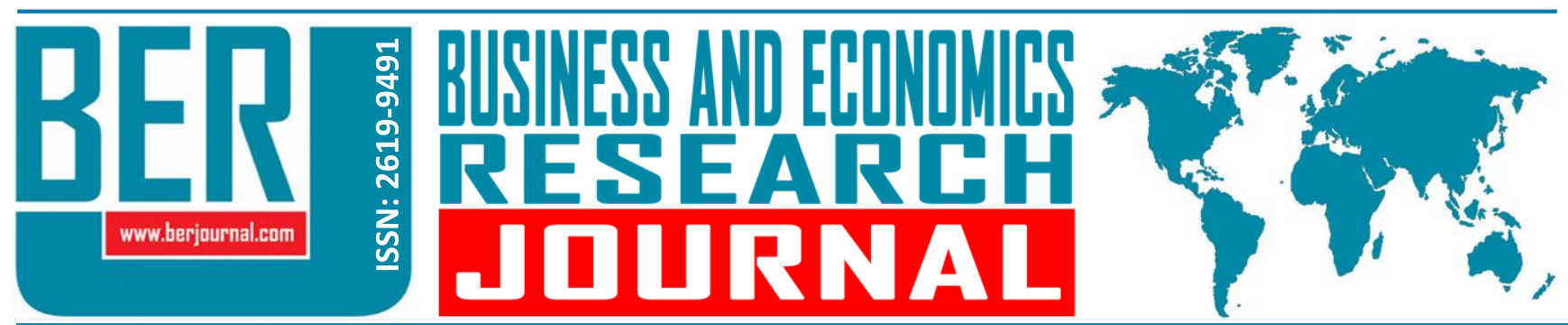

Business and Economics Research Journal Vol. 11, No. 3, 2020, pp. 609-620 doi: 10.20409/berj.2020.272

\title{
Exchange Rate and Import Price Pass-Through in Turkey
}

\section{Bilgin Bari ${ }^{\mathrm{a}}$}

Abstract: This study researches the effect of exchange rate movements on Turkey's domestic prices from 2003 through 2019. For the Turkish economy, the structural problems behind the inflation phenomenon are the dependency on imported intermediate goods for production and inflation expectations. Therefore, changes in exchange rates have a significant impact on domestic inflation. To analyze this process, the consumer price index (CPI), producer price index (PPI) and import price index (IPI) are examined by using VAR analysis. Estimations for two distinct periods-stable and upward courses in the exchange rate movement-yield different results. For the first stable period, import price and producer price shocks were more reflective than exchange rate shocks. Exchange rate shocks are found to be stronger than the import price shocks in the second period. The results show that structural problems of the Turkish economy related to production based on the import of intermediate goods, dollarization, and pricing behavior support exchange rate and imported price passthrough to consumer prices.
Keywords: Exchange Rate, Exchange Rate Pass-Through, Imported Prices Pass-

Through, Consumer Prices, Vector Auto Regressive Model

JEL: E31, F31, F41

Received : 12 February 2020

Revised : 20 March 2020

Accepted : 13 April 2020

Type : Research

\section{Introduction}

After the Turkish economy had indeed experienced high and chronic inflation until the beginning of 2000, a new economic program was started to implement to fight inflation. This program, prepared jointly with the IMF, was based on the exchange rate anchor. The main objective was to reduce inflation rates with the help of predictable and gradual increases in the fixed exchange rate. However, after the severe crises, the program collapsed and the exchange rate regime was changed as floating, in February 2001. These regime-switching gave rise to a structural change in the exchange rate behavior (Kara \& Ogunc, 2005: 14). With the implementation of the inflation targeting regime, this structural change in exchange rate behavior changed the dynamics of output, inflation and itself (Dogan, 2013: 37). There was also a paradigm shift in economic policy. A policy framework was created to strengthen the economic structure. Central bank independence was secured by law. The main objective was to prevent the central bank from funding public deficits by printing money. This, in a sense, eliminated one of the main factors behind the high inflation experienced in the 90s. When the monetary effects of inflation disappeared, a significant success was achieved in meeting inflation targets in the 2002-2005 period. During this period and until the emergence of the 2008 financial crisis, the exchange rate followed a stable course. Since 2011, there has been an increase in the exchange rate (Graph 1). This increase led to a process in which inflation targets could not be met. This is not the only reason, but there is a strong influence here. As stated in Kara et al. (2017: 10), annual consumer

a Asst.Prof., PhD., Anadolu University, Faculty of Economics and Administrative Sciences, Department of Economics, Eskisehir, Turkiye, bbari@anadolu.edu.tr (ORCID ID: 0000-0001-7665-2740) 
inflation in Turkey between 2006 and 2016 was 8.2 percent. In this period, exchange rate-related inflation was 1.3 points on average. The exchange rate contributes 2 points to annual inflation from 2011 to 2016 .

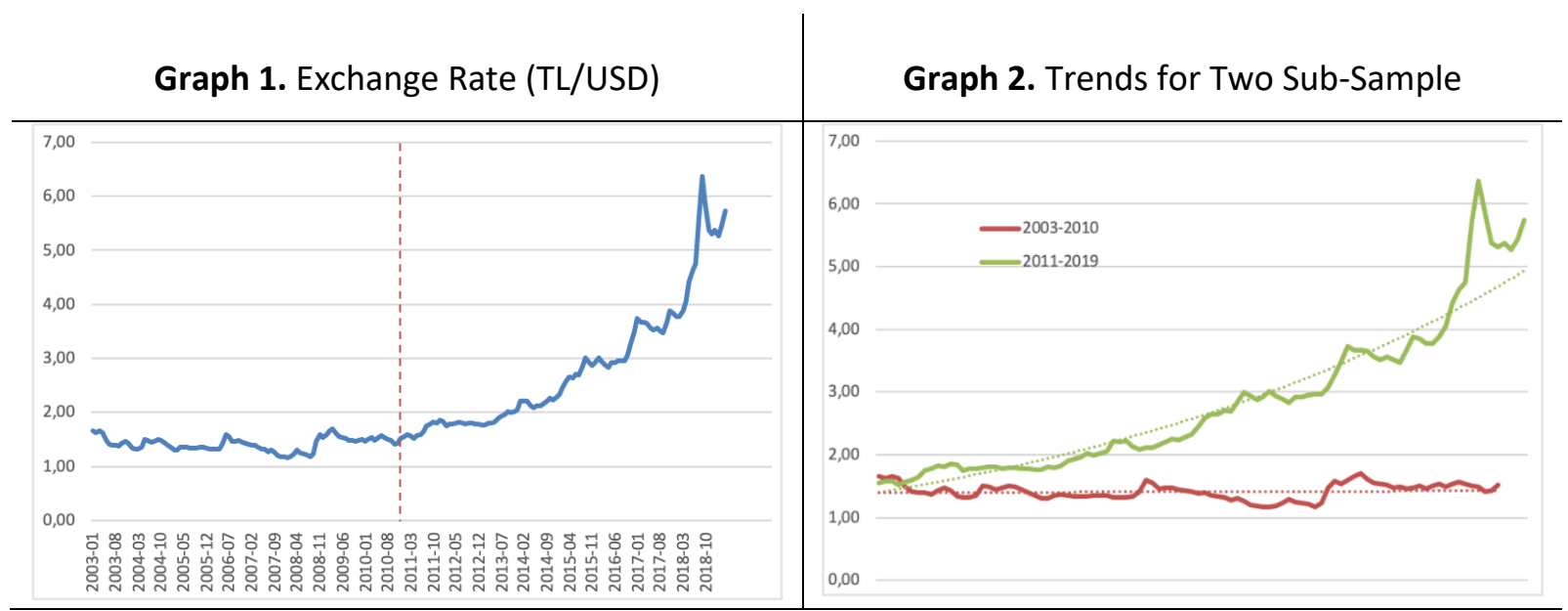

Source: Author's calculation, EDDS, CBRT.

When the path of the exchange rate is examined, we get some insights for the exchange rate dynamics. As stated above and seen in Graph 2, exchange rate dynamics can be divided into two periods. The first sample period is 2003M01-2010M12, and the second sample period is 2011M01-2019M04. Each sample has a different trend and gives insight about pricing behavior. On the graph, the first period is characterized by the horizontal trend (red dotted line) in the exchange rate while the second period is characterized by the positive trend (green dotted line). Perceptions of economic agents whether the exchange rate change is persistent or temporary may have differentiated the dynamics of the two periods. As a result of the exchange rate or import price shock, price setters keep or change their pricing decisions until they are sure of the duration and the dimension of the movement.

The effectiveness of the exchange rate and import price pass-through into consumer prices in Turkish economy is based on three main determinants. First, the share of imported goods in the intermediate goods and inputs used in the production in Turkey is very high. For example, the share of intermediate goods in total imports of Turkey is calculated as $72 \%$ for the period analyzed. This puts upward pressure on producer inflation (PPI). Secondly, there are some items in the CPI (consumer price index) basket are subject to tradability and commercial activities which are, foods and non-alcoholic beverages, main categories of energy, clothing, and footwear, etc. The TL value of imported goods may be influenced as a result of depreciation in TL. Atuk et al. (2014: 7) and Ozmen and Sarikaya (2014: 7) reveal that a substantial portion of the CPI basket is determined by Turkish lira-denominated import prices. Exchange rate pass-through into inflation varies in CPI subgroups and it has a significant impact on the food group (Ozmen \& Topaloglu, 2017: 12). Thirdly, exchange rate depreciation causes higher inflation expectations. Some firms base their pricing decisions by following exchange rate movements and this causes persistency in inflation. Kara et al. (2017) affirm that an important determinant of the pass-through of the exchange rate on inflation is the increasing expectations in the exchange rate. They find that that the effect of exchange rates on inflation was higher than the historical averages in periods when markets expected sharp depreciation. However, this effect is much lower during periods of exchange rate appreciation or moderate depreciation.

It is essential to understand the degree and timing of the total exchange rate pass-through in the determination of monetary policy. As stated in Choudhri and Hakura (2006: 635), a low ERPT facilitates policymakers in implementing an independent monetary policy and ensures effective inflation targeting. ERPT measures the sensitivity of import prices or domestic prices to changes in the exchange rate. These changes will also affect import prices and then move to the producer prices and consumer prices in an economy. Developing economies are more exposed to external shocks caused by capital flows due to structural problems such as asset and debt dollarization, financial imbalances, and lack of financial 
deepening. Therefore, the cost of fluctuations in exchange rates in developing countries is higher than in developed countries. Pricing behavior in the markets of developing countries is also more affected by the fluctuations in exchange rates. Moreover, the effect of exchange rate shocks on aggregate inflation in developing economies spread faster than industrial inflation (Devereux \& Yetman 2002: 367; Choudhri et al., 2005: 372).

Exchange rate movements affect domestic prices through direct and indirect channels in the inflation targeting model proposed by Svensson (2000: 158). First, changes in the exchange rate directly affect consumer prices because the CPI calculation basket includes imported final goods and services. Second, the exchange rate affects the relative price between domestic and foreign goods through the real exchange rate. Third, the change in expectations for exchange rates affects pricing behavior. Finally, changes in global macroeconomic conditions have an impact on domestic prices. According to the menu cost theory, the effect of large exchange rate movements on consumer prices is stronger. This is because firms make pricing over menu costs associated with price changes.

This paper examines the effects of the exchange rate movements on consumer prices in Turkey using monthly data from 2003M01 to 2019M04. We focus on the pass-through effect of the exchange rate, excluding other effects that determine inflation. In the analysis, the sensitivity of the consumer price in Turkey responding to the exchange rate movements is examined by estimating the Vector Auto Regressive (VAR) model for two distinct periods. In the next section, the empirical literature is reviewed. Section 3 describes the data set. Section 4 presents the methodology and empirical results. The final section is the conclusion.

\section{Literature Review}

VAR model of McCarthy (2007) is the most common methodology used to evaluate the exchange rate pass-through. The model includes the nominal exchange rate, industrial production, import prices, oil prices, producer prices, and consumer prices. The effect of pass-through is measured by impulse response functions and variance decompositions.

Jasova et al. (2016) examine the dynamic impact of large exchange rate movements on CPI inflation after the global financial crisis for a large group of economies for more than 20 years. They analyze the overall pattern of more than 20 years of exchange rate pass-through development for these economies. Their results find that the pass-through has been low and stable in advanced economies (AEs), and higher but declining in emerging economies.

Kara and Ogunc (2005) use VAR methodology to estimate the pass-through of the exchange rate and import prices into domestic prices before and after the adoption of the floating exchange rate regime in Turkey for the period 1995-2014. Their empirical findings indicate that the effect of pass-through has weakened and exchange rate pass-through decreases significantly after the adoption of the floating exchange rate regime in the long run. Furthermore, exchange rate shocks cause a persistent effect on inflation dynamics. The effect of pass-through on private manufacturing prices is stronger than that of consumer prices.

Yunculer (2011) examines the pass-through of the exchange rate and US Dollar denominated import prices into domestic prices by estimating the VAR model for the inflation targeting period and before in Turkey. Estimation results refer that the effect of pass-through to consumer prices is high for both external factors. On the other side, the pass-through on producer prices is more effective than import prices. Another important result is that the pass-through effect in the inflation targeting period is weaker than the previous period.

Atuk et al. (2013) estimate the VECM model to analyze the impact of PPI on CPI for the period of 2003-2013 in the Turkish economy. The effect of pass-through is faster for producer prices. This is because price components such as taxes and services are not included in producer prices. According to the results of 
the study, changes in taxes may eliminate the effects of exchange rate movements. This situation reveals non-linear dynamics during the pass-through process.

Sekmen and Siklar (2015) search for whether "fear of floating" in a low and stable inflation environment with the adoption of the inflation targeting in Turkey. They employ an ARDL model to estimate long-run ERPT between 1994 and 2012. Their results show that the level of pass-through has decreased significantly and fear of floating has weakened in the period of inflation targeting.

Ozmen and Topaloglu (2017) examine the pass-through effect by estimating a separate VAR model for each of the subcomponents of CPI for the period of 2005-2015 in Turkey. The impulse response function of each component is obtained to monitor their positive response to changes in exchange rates and import prices. The results show that the pass-through effect is higher in food and services and goods and energy groups. Moreover, the pass-through effect is stronger on total inflation.

Kara et al. (2017) investigate the effects of the main components of CPI on itself by employing a reduced-form of Time Varying Parameter Phillips curve for the period of 2006-2016 in Turkey. The timevarying fixed term in the model represents a trend for persistent inflation based on inflation expectations. The estimation results show that this constant value contributes to the headline inflation by $4 \%$. Besides, the effect of the pass-through of import prices into inflation has declined as the decrease in oil prices was not fully reflected in domestic market prices.

Ciftci ve Yilmaz (2018) examine the non-linear dynamics of pass-through and inflation persistence between 2003 and 2017 in Turkey. They use Smooth Transition Regression (STR) models to analyze the magnitude of exchange rate movements in the periods of persistence in inflation. They find that the exchange rate and import price pass-through into producer prices is more effective in the high depreciation regime. In the case of a high import price shock, the effect of pass-through into consumer prices and persistence in inflation are high.

Ogunc et al. (2018) research the effects of the exchange rate and import prices on inflation by using a Bayesian VAR model in Turkey. The identification strategy in the model is based on a set of zero restrictions and the use of exogenous control variables. The results show that the pass-through of the exchange rate into inflation is higher than that of import prices. Exchange rate and import price shocks have a rapid impact on inflation. They find that the degree of pass-through of nominal wages into inflation close to that of the exchange rate.

Aydogus et al. (2018) investigate the effect of the exchange rate and import price pass-through on domestic prices by using an input-output model. They use different variables related to pass-through in the model developed for a sample of countries. The results show that the pass-through effect is high in economies based on imported intermediate goods. The monetary policy stance does not have a direct impact on the effects of pass-through. On the contrary, the changes in the price level are positively related to the nominal exchange rate fluctuations. Hence, the real effective exchange rate affects negatively on the changes in the price level.

The contribution of this paper to the literature is that it examines the effectiveness of the exchange rate pass-through process for two distinct periods in the floating exchange rate regime. Because characteristics of exchange rate behavior are different for each period as explained before, we provide evidence that a positive trend in exchange rate movements leads to pass-through more strongly into consumer prices.

\section{Empirical Analysis}

\subsection{Data}

In the analysis, monthly data is used for four macroeconomic variables. There are two subsamples for the period of 2003M01-2010M12 and period of 2011M01-2019M04. All the data is obtained from the Electronic Data Dissemination System (EDDS) of the Central Bank of the Republic of Turkey (CBRT). The 
variables are nominal exchange rate (NER), import price index (IPI), producer price index (PPI), and consumer price index (CPI). For the nominal exchange rate, the buying rate of average nominal TL/USD is used as most of the Turkish imports are traded in the US Dollar. Moreover, the value of USD has a more substantial influence on inflation expectations (Kara et al., 2017:14). The unit value of the import price index in the US Dollar is used as a proxy for import prices. This measures the impact of import prices on inflation caused by global conditions. It also backs the selection of the TL/USD rate as the exchange rate variable (Yunculer, 2011:75). The model is harmonized by using the exchange rate and import price index (IPI) together. Instead of the producer price index (PPI), the manufacturing industry producer price index (MPI) is used. MPI excludes some components like mining, energy, and agricultural prices, which are driven mostly by exogenous factors. This is because MPI does not contain specific components, such as mining, energy, and agriculture prices, which are highly sensitive to the effects of external factors. Hereby we decompose the effects of imported intermediate goods in production and on pricing decisions of firms. Moreover, the MPI reflects the overall producer pricing behavior as it accounts for approximately 75 percent of the total PPI. For the CPI, Index D is used as the core CPI inflation to see the changes in the main trend in inflation. X12 method is used for seasonal adjustment of data. Also, the natural logarithms of the data are used for the elimination of the effect of seasonal interruptions and heteroscedasticity.

\subsection{Model}

There are two primary approaches to measure ERPT: Single equation and system based. The single equation methods can be used to explain incomplete ERPT, which has asymmetric and non-linear characteristics between variables. System models allow endogeneity among the variables. In other words, all variables are endogenous. If there are no structural break and non-linearities, the Johansen systems method and a VAR model can be used to test multiple relationships among endogenous variables (Aron et al., 2014:121). VAR models allow researchers to obtain the dynamic effects of the exchange rate on consumer and producer prices. The most popular system method used to analyze ERPT is the price distribution chain in a VAR model, which allows causal relationships. This study examines ERPT by estimating a VAR model developed by McCarthy ( 2000 and 2007) because the model is compatible with pricing channels in the Turkish economy, as mentioned in Kara and Ogunc (2008 and 2011). The model is based on a distribution chain that includes importers, producers, and consumers. In this respect, price indexes related to consumer, producer and import prices are used. These price indicators at each stage in period $t$ assumed to consist of several components. The shock at each stage is the part of a stage's inflation that cannot be explained by information at period t-1 and the previous stages of the distribution cycle. The main assumption in the model is that exchange rate shocks arise directly from exchange rate dynamics (equation 1). For the structure of the Turkish economy, capital flows are sensitive to local and global conditions. This is the main determinant of variability in the exchange rate. Changes in the exchange rate affect import prices. Pricing channel works from import prices to producer prices and from producer prices to consumer prices (from equation 2 to 4 ). Another assumption is that all price indexes have positive transmission effects on each other. The model can be represented as follows:

$$
\begin{aligned}
& \Delta e x c_{t}=E_{t-1}\left(\Delta e x c_{t}\right)+\varepsilon_{t}^{\Delta e x c} \\
& \pi_{t}^{I P I}=E_{t-1}\left(\pi_{t}^{I P I}\right)+\alpha_{1} \varepsilon_{t}^{\Delta e x c}+\varepsilon_{t}^{I P I} \\
& \pi_{t}^{P P I}=E_{t-1}\left(\pi_{t}^{P P I}\right)+\beta_{1} \varepsilon_{t}^{\Delta e x c}+\beta_{2} \varepsilon_{t}^{I P I}+\varepsilon_{t}^{P P I} \\
& \pi_{t}^{C P I}=E_{t-1}\left(\pi_{t}^{C P I}\right)+\theta_{1} \varepsilon_{t}^{\Delta e x c}+\theta_{2} \varepsilon_{t}^{I P I}+\theta_{3} \varepsilon_{t}^{P P I}+\varepsilon_{t}^{C P I}
\end{aligned}
$$


In the equations 1-4, $\Delta \operatorname{exc}_{t}$ is the first difference of the logarithm of the nominal exchange rate. $\pi_{t}^{I P I}, \pi_{t}^{P P I}, \pi_{t}^{C P I}$ represent the first difference of the logarithm of the imported price index, producer price index and consumer price index, respectively. $\varepsilon_{t}^{\Delta e x c}, \varepsilon_{t}^{I P I}, \varepsilon_{t}^{P P I}$ and $\varepsilon_{t}^{C P I}$ indicate the impact from shocks to the nominal exchange rate, import prices, producer prices, and consumer prices, respectively. $E_{t-1}(\bullet)$ is the expectation of the related variable based on the information obtained at the end of the previous period. It is assumed that structural shocks are serially uncorrelated and orthogonal across equations. Besides, expectations are included in the model by using linear projections of the lags of the variables in the system. Given this structure of the model, we can use an unrestricted VAR model with $l$ lags borrowed Liu and Chen (2017: 4) as below:

$$
V_{t}=a_{0} D_{t}+\sum_{i=1}^{l} C_{i}+V_{t-1}+u_{t}
$$

In equation $5, D_{t}$ is a $(k \times 1)$ vector of all deterministic variables, $C_{1}, \ldots, C_{k}$ are $(k \times k)$ matrix of coefficients, $V_{t}=\left(V_{1 t}, V_{2 t}, \ldots, V_{k t}\right)$ is a vector of $k$ variables, $u_{t}$ is a $(k \times 1)$ column vector of innovations.

Initially, a unit root test should be performed to determine the appropriate specification for VAR estimation. The Augmented Dickey-Fuller (ADF) unit root test is used to determine whether there is a stochastic trend in each variable. Unit root tests were performed on the logarithms of variables. The results of ADF tests for each sample are presented in Table 1. Import price index, manufacturing PPI and CPI are nonstationary, but the exchange rate is stationary for the first sample, while all series are non-stationary for the second sample at $5 \%$ critical value.

Table 1. ADF Test Results

\begin{tabular}{c|c|c|c|c|c|c} 
& \multicolumn{7}{c}{ First Sample } & \multicolumn{3}{c}{ ADF test with Intercept } \\
\hline & \multicolumn{7}{|c|}{ Variables } & t-Statistic & p-value & $\begin{array}{c}\text { Order of } \\
\text { Integration }\end{array}$ & t-Statistic & p-value & $\begin{array}{c}\text { Order of } \\
\text { Integration }\end{array}$ \\
\hline Exc Rate & -3.0511243 & 0.0340 & $\mathrm{I}(0)$ & -6.918554 & 0.0000 & $\mathrm{I}(1)$ \\
\hline IPI & -5.786571 & 0.0000 & $\mathrm{I}(1)$ & -6.752236 & 0.0000 & $\mathrm{I}(1)$ \\
\hline PPI & -6.939136 & 0.0000 & $\mathrm{I}(1)$ & -6.696108 & 0.0000 & $\mathrm{I}(1)$ \\
\hline CPI & -5.724681 & 0.0000 & $\mathrm{I}(1)$ & -6.487632 & 0.0000 & $\mathrm{I}(1)$ \\
\hline & \multicolumn{7}{|c|}{ ADF test with Intercept and Trend } \\
\hline Exc Rate & -3.215692 & 0.0378 & $\mathrm{I}(0)$ & -7.010460 & 0.0000 & $\mathrm{I}(1)$ \\
\hline IPI & -5.733249 & 0.0000 & $\mathrm{I}(1)$ & -6.734066 & 0.0000 & $\mathrm{I}(1)$ \\
\hline PPI & -6.885305 & 0.0000 & $\mathrm{I}(1)$ & -6.730903 & 0.0000 & $\mathrm{I}(1)$ \\
\hline CPI & -5.683655 & 0.0000 & $\mathrm{I}(1)$ & -6.793032 & 0.0000 & $\mathrm{I}(1)$ \\
\hline
\end{tabular}

The VAR model was estimated for the sample periods separately. For the first sample, some of the variables, such as all price indexes are first difference stationary and the exchange rate level is level stationary. Before estimation, Johansen approach is employed to test the co-integration relationship among price index variables. If there is no co-integration among them, the difference of IPI, CPI and PPI can be used in the VAR estimation. Johansen co-integration test results show that there is no co-integration in price index variables in the first sample. Therefore, we estimate a VAR model including first differences of the variables which are integrated of degree 1 , that is I(1), and the level values of the exchange rate, that is I(0), following the Hamilton (1994: 652). In other words, the first difference of logarithms of price indexes is used, while the log of the exchange rate is used. For the second sample, the VAR model is estimated because all variables are first difference stationary, and there is no cointegrating relationship among the variables. The cointegration test results for both samples are given in Table 3 at the appendix.

The selection of appropriate lag length for the models is important because adding more lags to the model increases the power of fit. Moreover, limiting the lag length may lead to model misspecification. For the two models, optimal lag lengths are determined by different criteria used in the literature. They are 
provided in Table 4 at the appendix. Optimal lag length is determined as 4 for the first model and 3 for the second model. LM tests result also support that there is no autocorrelation problem in the models. This implies that model specifications with these lag lengths are sufficient to eliminate the auto-correlation problem. For the stability of the models, all the inverse roots are less than one. The roots are within the unit circle for both models. White test results show that there is no heteroskedasticity problem in these two models. Both models passed residual tests. Test results for residual diagnostics are given in Figure 5, Table 5, and Table 6 at the appendix.

\section{Empirical Results}

After confirming the residual diagnosis, we use impulse response functions, variance decomposition, and historical decomposition to analyze the dynamic behavior of the models. Impulse responses, variance, and historical decompositions are computed using the same ingredients, which means that they package the same information in different ways. The impulse response function shows the effect of a standard deviation shock on a variable on the present and future values of other variables in the system, and the directionmagnitude of this effect. Figure 1 and Figure 2 show the responses of consumer prices to one standard deviation shocks in the exchange rate, import prices, and producer prices in the first and second samples. For the first sample, the impact of the exchange rate shock on the CPI is negative. The effect of PPI and IPI on consumer prices is positive. The effect of PPI on CPI increases rapidly and reaches its highest point in the second month. The impact of import prices to CPI reaches the highest point after five months even though they have a negative effect in the first two months. The results show that pass-through from the exchange rate to the CPI works through imported price and PPI. For the first period, our study produces similar findings as in the studies of Kara and Ogunc (2005), Yunculer (2011), and Sekmen and Siklar (2015). These are mostly related to stability in the exchange rate in this term. For the second sample, all shocks have a positive effect on CPI. Consumer prices are more sensitive to changes in exchange rates than to changes in import and producer prices. Notably, a shock on the exchange rate is quick and increases speedily in the first four months. It reaches the highest point in the fourth month and continues persistently. Import price shock also shows a regular increasing trend. In this period, both the exchange rate and import prices had a significant impact on the CPI. Consumer prices are more directly affected by the exchange rate than the import price compared with the first period. These empirical results support the results noted in Ozmen and Topaloglu (2017), Kara et al. (2013), Ciftci and Yilmaz (2018), and Ogunc et al. (2018). According to the results of impulse responses, the extent of the exchange rate pass-through is significantly lower in the first period than in the second period. The pass-through dynamics of external shocks differ for each period.

Figure 1. Response of CPI to Cholesky One S.D. Innovations in the First Sample

(1)

Figure 2. Response of CPI to Cholesky One S.D. innovations in the Second Sample 
Using variance decomposition in CPI for each period, we compare the importance of external shocks on inflation. The results in Table 2 highlight similar results to those obtained from impulse response functions. For the first sample, CPI itself caused $40 \%$ of its variability. Then import price shocks account for almost $23 \%$ of the CPI's variance after 12 lags. The producer price explains almost $22 \%$ of the CPI's variance. The exchange rate claims $13.3 \%$ of the CPI's variance. For the second sample, CPI itself caused $12 \%$ of its variability. The most significant contribution stems from the exchange rate. Exchange rate shock makes up $22.3 \%$ in the beginning and then the percentage increases to almost $66 \%$ after four-month. It keeps a study percentage on this level. Import price shock explains $20 \%$ of the CPI's variance.

Table 2. Variance Decomposition of CPI

\begin{tabular}{c|c|c|c|c|c|c|c|c}
\multicolumn{5}{|c|}{ First sample } & \multicolumn{4}{c}{ Second sample } \\
\hline Period & EXC & IPI & PPI & CPI & EXC & IPI & PPI & CPI \\
\hline $\mathbf{1}$ & 3.5902 & 8.1697 & 12.9321 & 75.3078 & 22.3864 & 6.7070 & 0.0126 & 70.8938 \\
\hline $\mathbf{2}$ & 2.9385 & 6.8943 & 26.2194 & 63.9475 & 51.7732 & 8.4709 & 0.2192 & 39.5365 \\
\hline $\mathbf{3}$ & 4.7709 & 8.4598 & 31.4387 & 55.3304 & 61.3918 & 9.6158 & 0.3129 & 28.6794 \\
\hline $\mathbf{4}$ & 7.0709 & 8.6388 & 30.6999 & 53.5901 & 65.4861 & 11.1688 & 0.2191 & 23.1258 \\
\hline $\mathbf{5}$ & 7.7220 & 20.2872 & 25.8353 & 46.1553 & 66.9808 & 12.7877 & 0.2876 & 19.9437 \\
\hline $\mathbf{6}$ & 10.0428 & 22.9043 & 24.0447 & 43.0080 & 67.5031 & 14.2792 & 0.4953 & 17.7221 \\
\hline $\mathbf{7}$ & 11.8977 & 23.0259 & 23.5229 & 41.5533 & 67.6836 & 15.5573 & 0.7125 & 16.0464 \\
\hline $\mathbf{8}$ & 12.8311 & 23.7252 & 22.9200 & 40.5235 & 67.6995 & 16.6570 & 0.8961 & 14.7472 \\
\hline $\mathbf{9}$ & 13.2507 & 23.7192 & 22.7645 & 40.2655 & 67.5664 & 17.6303 & 1.0431 & 13.7600 \\
\hline $\mathbf{1 0}$ & 13.3091 & 23.7682 & 22.6664 & 40.2561 & 67.3150 & 18.5030 & 1.1555 & 13.0263 \\
\hline $\mathbf{1 1}$ & 13.3489 & 23.8032 & 22.6462 & 40.2014 & 66.9975 & 19.2808 & 1.2319 & 12.4897 \\
\hline $\mathbf{1 2}$ & 13.3412 & 23.7911 & 22.6794 & 40.1881 & 66.6607 & 19.9672 & 1.2743 & 12.0976 \\
\hline Note: Cholesky ordering: $\mathrm{EXC}, \mathrm{IPI}, \mathrm{PPI}$ and CPI.
\end{tabular}

Figure 3 and Figure 4 show the historical decomposition of CPI for each period, respectively. The historical decomposition measures deviations from the baseline forecast of CPI due to a shock. Baseline forecast refers to dynamic forecasts of each endogenous variable generated from the VAR model. The results show that import price shock has a significant on deviations for the first period, while exchange rate shock has a significant effect for the second period.

Figure 3. Historical Decomposition of CPI for the First Sample

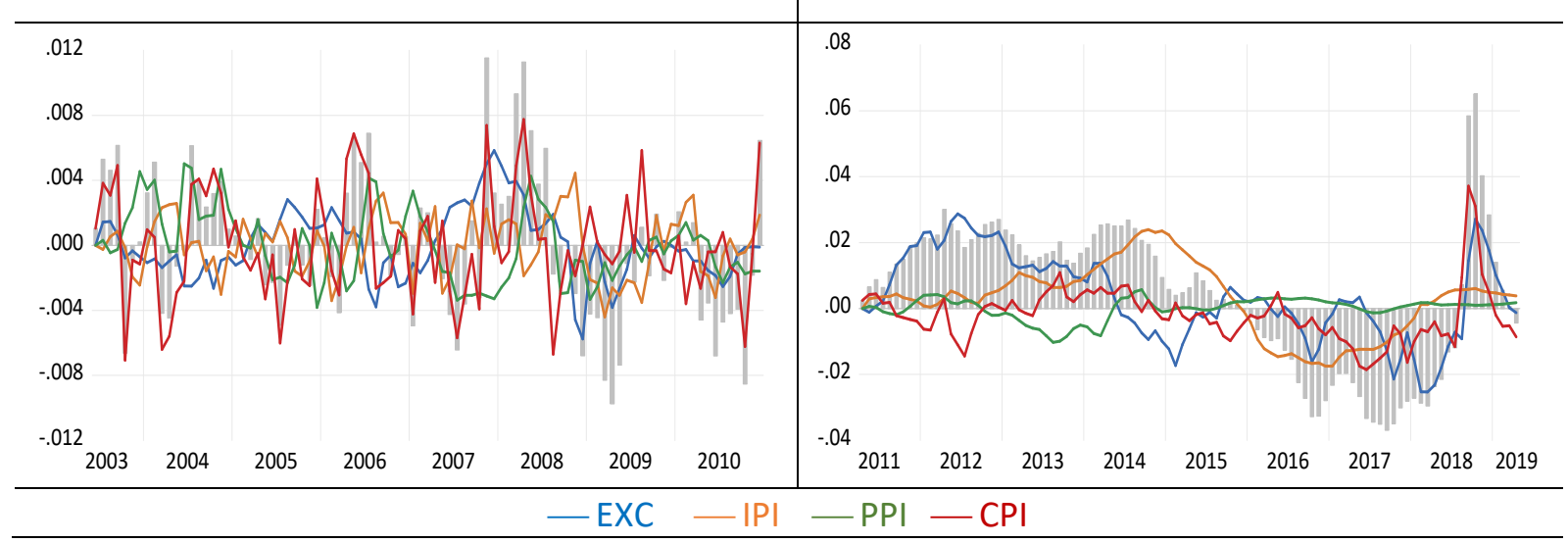




\section{Conclusion}

This study builds a VAR model to compare the pass-through effects of the exchange rate and import prices into consumer prices for two sampling periods using monthly data between 2003M01-2019M04. For the first period, import price and producer prices are the main determinants of inflation. In this period, the exchange rate follows a stable path and has no significant effect on pricing decisions. However, this relation changes in the second period in where the exchange rate has an upward trend. This leads to pass-through more strongly into consumer prices.

The results highlight the main characteristics of the Turkish economy related to the exchange rate pass-through. Firstly, the cost channel works effectively. Imported consumer goods in the consumer price basket and imported inputs used in production affect exchange rate pass-through. The exchange rate has a more substantial impact on domestic prices since the structure of production is highly dependent on the energy and other intermediate goods. Secondly, expectations have an impact on the exchange rate passthrough into inflation. When the exchange rate increases chronically, pricing behavior changes. Some firms base their pricing decisions by following exchange rate movements and this causes persistence in inflation. This persistence in inflation also affects pricing decisions due to the increase in inflation expectations. This is the result of firms who want to protect themselves against price increases. Lastly, an increase in dollarization affects exchange rate movements as volatility and rise. This causes an exchange rate-inflation cycle.

This paper presents the impact of the exchange rate and import prices on domestic inflation while highlighting the structural problems that create this impact. For future research, the effect of structural problems mentioned above on sectoral inflation should be investigated.

\section{Disclosure Statements}

1. The author of this article confirms that her work complies with the principles of research and publication ethics.

2. No potential conflict of interest was reported by the author.

3. This article was screened for potential plagiarism using a plagiarism screening program.

\section{References}

Aron, J., Macdonald, R., \& Muellbauer, J. (2014). Exchange rate pass-through in developing and emerging markets: A survey of conceptual, methodological and policy issues, and selected empirical findings. The Journal of Development Studies, 50(1), 101-143.

Atuk, O., Ozmen, M. U., \& Sevinc, O. (2013). Treatment of seasonal products and CPI volatility. Central Bank Review, 13(1), 51-82.

Atuk, O., Aysoy, C., Ozmen, M. U., \& Sarikaya, C. (2014). Türkiye'de enflasyonun iş çevrimlerine duyarlılı̆̆ı: Çıktı açığına duyarlı TÜFE alt gruplarının saptanması (Sensitivity of inflation to business cycles in Turkey: Determining CPI subitems sensitive to output gap- available only in Turkish). CBRT Working Paper, 14/37.

Aydogus, O., Deger, C., Caliskan, E. T. \& Gunal, G. G. (2018). An input-output model of exchange rate pass-through. Economic System Research, 30(3), 323-336.

Choudhri, E. U., Faruqee, H., \& Hakura, D. (2005). Explaining the exchange rate pass-through in different prices. Journal of International Economics, 65(2), 349-374.

Choudhri, E. U., \& Hakura, D. S. (2006). Exchange rate pass-through to domestic prices: Does the inflationary environment matter? Journal of International Money and Finance, 25(4), 614-639.

Ciftci, M., \& Yilmaz, M. H. (2018). Nonlinear dynamics in exchange rate pass-through and inflation persistence: The case of Turkish economy. Asian Journal of Economic Modelling, 6(1), 8-20.

Devereux, M. B., \& Yetman, J. (2002). Price setting and exchange rate pass-through: Theory and evidence. HKIMR Working Paper, No. 22/2002. 
Dogan, B. S. (2013). Asymmetric behavior of the exchange rate pass-through to manufacturing prices in Turkey. Emerging Markets Finance and Trade, 49(3), 35-47.

Hamilton, J. (1994). Time series analysis. Princeton University Press.

Jasova, M., Moessner, R., \& Takats, E. (2016). Exchange rate pass-through: What has changed since the crisis? BIS Working Papers, No. 583.

Kara, A. H., Ogunc, F., \& Sarikaya, C. (2017). Inflation dynamics in Turkey: A historical accounting. CBRT Research Notes in Economics, No. 1703.

Kara, A. H., Kucuk-Tuger, H., Ozlale, U., Tuger, B., Yavuz, D., \& Yucel, E. M. (2005). Exchange rate pass-through in Turkey: Has it changed and to what extent? CBRT Working Paper, No: 05/04.

Kara, A. H., \& Ogunc, F. (2005). Exchange rate pass-through in Turkey: It is slow, but is it really low? CBRT Working Paper, No: 05/10.

Kara, A. H., \& Ogunc, F. (2008). Inflation targeting and exchange rate pass-through: The Turkish experience. Emerging Markets Finance \& Trade, 44(6), 52-66.

Kara, A. H., \& Ogunc, F. (2011). Döviz kuru ve ithalat fiyatlarının enflasyona etkisi. CBRT Policy Note, No:2011/14.

Kara, A. H., Ogunç, F., Sarikaya, C., \& Ozmen, M. U. (2017). Exchange rate pass-through: Is there a magical coefficient. $\begin{array}{llll}\text { Retrieved } \quad \text { June } & 12, & \text { 2019, }\end{array}$ http://tcmbblog.org/wps/wcm/connect/blog/en/main+menu/analyses/exchange+rate+pass-through

Liu, H. Y., \& Chen, X. L. (2017). The imported price, inflation and exchange rate pass-through in China. Cogent Economics \& Finance, 5(1), 1279814.

Mccarthy, J. (2000). Pass-through of exchange rates and import prices to domestic inflation in some industrialized economies. BIS Working Papers, No. 79.

Mccarthy, J. (2007). Pass-through of exchange rates and import prices to domestic inflation in some industrialized economies. Eastern Economic Journal, 33(4), 511- 537.

Ogunc, F., Ozmen, M. U., \& Sarikaya, C. (2018). Inflation dynamics in turkey from a Bayesian perspective. CBRT Working Paper, No: 18/10.

Ozmen, M. U., \& Sarikaya, C. (2014). Enflasyonun çıktı açığı ve kredilere duyarlılığı (Sensitivity of inflation to output gap and loans- available only in Turkish). CBRT Research Notes in Economics, 2014/17.

Ozmen, M. U., \& Topaloglu, M. (2017). Disaggregated evidence for exchange rate and import price pass-through in the light of identification issues, aggregation bias and heterogeneity. CBRT Working Paper, No: 17/08.

Sekmen, T., \& Siklar, I. (2015). Fear of floating in Turkey. Business and Economic Research, 5(2), 288-307.

Svensson, L. E. (2000). Open-economy inflation targeting. Journal of International Economics, 50, $155-183$.

Yunculer, C. (2011). Pass-through of external factors into price indicators in Turkey. Central Bank Review, 11(2), 71-84. 


\section{Appendix}

Table 3. Johansen Co-integration Test Results

\begin{tabular}{|c|c|c|c|c|c|}
\hline \multirow{7}{*}{$\begin{array}{c}\text { First } \\
\text { sample }\end{array}$} & \multicolumn{5}{|c|}{ Unrestricted co-integration rank test (trace) } \\
\hline & $\begin{array}{l}\text { Hypothesized } \\
\text { No. of CE(s) }\end{array}$ & Eigenvalue & $\begin{array}{c}\text { Trace } \\
\text { Statistics }\end{array}$ & $\begin{array}{c}0.05 \\
\text { Critical } \\
\text { value }\end{array}$ & Prob. \\
\hline & None & 0.191632 & 29.38737 & 29.7970 & 0.0557 \\
\hline & At most 1 & 0.081038 & 9.602743 & 15.49471 & 0.3125 \\
\hline & At most 2 & 0.018571 & 1.743300 & 3.841465 & 0.1867 \\
\hline & \multicolumn{5}{|c|}{ Unrestricted Cointegration Rank Test (Maximum Eigenvalue) } \\
\hline & $\begin{array}{l}\text { Hypothesized } \\
\text { No. of CE(s) }\end{array}$ & Eigenvalue & $\begin{array}{l}\text { Max-Eigen } \\
\text { Statistic }\end{array}$ & $\begin{array}{c}0.05 \\
\text { Critical } \\
\text { value }\end{array}$ & Prob. \\
\hline \multirow{3}{*}{$\begin{array}{l}\text { tested for } \\
\text { CPI, PPI, IPI }\end{array}$} & None & 0.149343 & 14.71895 & 21.13162 & 0.3091 \\
\hline & At most 1 & 0.095874 & 9.171535 & 14.26460 & 0.2722 \\
\hline & At most 2 & 0.016264 & 1.492185 & 3.841465 & 0.2219 \\
\hline \multirow{12}{*}{$\begin{array}{l}\text { Second } \\
\text { sample }\end{array}$} & \multicolumn{5}{|c|}{ Unrestricted co-integration rank test (trace) } \\
\hline & $\begin{array}{l}\text { Hypothesized } \\
\text { No. of CE(s) }\end{array}$ & Eigenvalue & $\begin{array}{c}\text { Trace } \\
\text { Statistics }\end{array}$ & $\begin{array}{c}0.05 \\
\text { Critical } \\
\text { value }\end{array}$ & Prob. \\
\hline & None & 0.127461 & 26.83754 & 47.85613 & 0.8603 \\
\hline & At most 1 & 0.086314 & 13.74818 & 29.79707 & 0.8545 \\
\hline & At most 2 & 0.032798 & 5.082389 & 15.49471 & 0.8000 \\
\hline & At most 3 & 0.019403 & 1.880964 & 3.841465 & 0.1702 \\
\hline & \multicolumn{5}{|c|}{ Unrestricted Cointegration Rank Test (Maximum Eigenvalue) } \\
\hline & $\begin{array}{l}\text { Hypothesized } \\
\text { No. of CE(s) }\end{array}$ & Eigenvalue & $\begin{array}{l}\text { Max-Eigen } \\
\text { Statistic }\end{array}$ & $\begin{array}{c}0.05 \\
\text { Critical } \\
\text { value }\end{array}$ & Prob. \\
\hline & None & 0.127461 & 13.08936 & 27.58434 & 0.8799 \\
\hline & At most 1 & 0.086314 & 8.665792 & 21.13162 & 0.8584 \\
\hline & At most 2 & 0.032798 & 3.201425 & 14.2646 & 0.9324 \\
\hline & At most 3 & 0.019403 & 1.880964 & 3.841465 & 0.1702 \\
\hline
\end{tabular}


Exchange Rate and Import Price Pass-Through in Turkey

Table 4. Lag Order Selection for The Models

\begin{tabular}{|c|c|c|c|c|c|}
\hline & Lag & LR & AIC & $\mathrm{SC}$ & $\mathrm{HQ}$ \\
\hline \multirow{7}{*}{$\begin{array}{c}\text { Model } \\
1\end{array}$} & 0 & NA & -21.6644 & -21.5478 & -21.6176 \\
\hline & 1 & 254.049 & -24.5359 & -23.7279 & -24.3017 \\
\hline & 2 & 46.3735 & -24.6369 & -23.1215 & -24.0281 \\
\hline & 3 & 17.1784 & -24.7583 & $-23.9530^{*}$ & -24.1622 \\
\hline & 4 & $33.4613^{*}$ & $-24.7770 *$ & -22.7766 & $-24.3555^{*}$ \\
\hline & 5 & 20.7137 & -24.6187 & -22.2589 & -23.7234 \\
\hline & 6 & 17.2457 & -24.3891 & -21.7044 & -23.4479 \\
\hline \multirow{7}{*}{$\begin{array}{c}\text { Model } \\
2\end{array}$} & 0 & NA & -10.2031 & -10.0949 & -10.1594 \\
\hline & 1 & 1340.352 & -24.9228 & -24.3817 & -24.7042 \\
\hline & 2 & 168.0467 & -25.4086 & -24.0017 & -24.8403 \\
\hline & 3 & $80.34810 *$ & $-25.4950^{*}$ & $-24.5210^{*}$ & $-25.1016 *$ \\
\hline & 4 & 21.50435 & -25.3061 & -23.4666 & -24.5633 \\
\hline & 5 & 17.09198 & -25.1500 & -22.8773 & -24.2320 \\
\hline & 6 & 18.34981 & -25.0429 & -22.3373 & -23.9501 \\
\hline $\begin{array}{l}\text { * indicates } \\
\text { LR: seque } \\
\text { AIC: Akaik } \\
\text { SC: Schwa } \\
\text { HQ: Hann }\end{array}$ & $\begin{array}{l}\text { rder s } \\
\text { nodifi } \\
\text { ormati } \\
\text { ormat } \\
\text { dinn in }\end{array}$ & $\begin{array}{l}\text { y criterion for } 1 \\
\text { t statistic (each } \\
\text { on } \\
\text { ion } \\
n \text { criterion }\end{array}$ & level) & & \\
\hline
\end{tabular}

Figure 5. AR Roots Graph

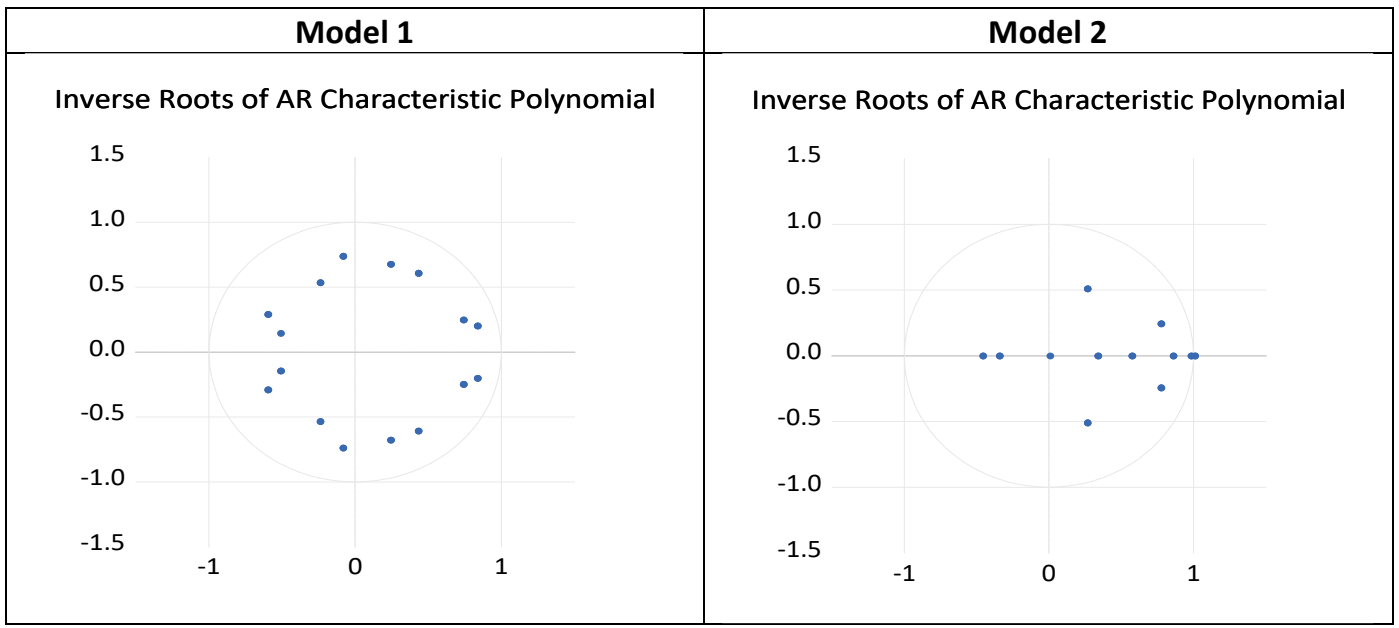

Table 5. LM Test Results for Autocorrelation

\begin{tabular}{|c|c|c|}
\hline & Lags & Probability \\
\hline \multirow{3}{*}{ Model 1 } & 1 & 0.2788 \\
& 2 & 0.8464 \\
& 3 & 0.0503 \\
Model 2 & 4 & 0.1728 \\
\hline \multirow{2}{*}{ Mod } & 0.1319 \\
& 1 & 0.5905 \\
& 3 & 0.6728 \\
& 4 & 0.3446 \\
\hline
\end{tabular}

Table 6. White Test Results for Heteroskedasticity

\begin{tabular}{|c|c|c|}
\hline & Chi-sq & Probability \\
\hline Model 1 & 312.3100 & 0.6103 \\
\hline Model 2 & 255.4678 & 0.2353 \\
\hline
\end{tabular}

